\title{
The Effect of Financial and Corporate Governance Factors on Dividend Policy of Manufacturing Companies
}

\author{
Muhammad Bagas Syabana Hardianto ${ }^{1 *}$ \\ 1 Departement of Management, Faculty of Economics and Business, Universitas Negeri \\ Surabaya, Indonesia
}

\begin{tabular}{|c|c|}
\hline ARTICLE INFO & ABSTRACT \\
\hline $\begin{array}{l}\text { ISSN: 2723-1097 } \\
\text { Keywords: } \\
\text { Corporate } \\
\text { Governance; Dividend } \\
\text { Policy; Financial } \\
\text { Ratio; Firm Size, } \\
\text { Growth. }\end{array}$ & $\begin{array}{l}\text { Dividend payment is one of the rewards given by the company to investors for the } \\
\text { time, risk, and commitment of a number of funds that have been given to the } \\
\text { company. The distribution of dividends is generally carried out at the end of each } \\
\text { financial reporting year and has obtained the approval of the General Meeting of } \\
\text { Shareholders (RUPS). However, the distribution of company dividends is not } \\
\text { mandatory, the agreement on the deal and certain factors. This study aims to } \\
\text { identify the influence of financial factors and corporate governance (institutional } \\
\text { ownership and managerial ownership) on company dividend policy. The type of } \\
\text { data used in this research is quantitative data, which comes from secondary sources. } \\
\text { The method used is purposive sampling with criteria, namely manufacturing } \\
\text { companies in the consumer goods sector listed on the Indonesia Stock Exchange for } \\
\text { the period 2016-2019. The number of samples in this research is 34. The data } \\
\text { analysis technique used in this study is multiple linear regression. The results of } \\
\text { this study indicate that financial factors such as profitability, company size, and } \\
\text { company growth have an effect on dividend policy. Meanwhile, liquidity and } \\
\text { leverage have no effect on dividend policy. In corporate governance, it is known } \\
\text { that managerial ownership and ownership have no effect on dividend policy. }\end{array}$ \\
\hline
\end{tabular}

\section{Introduction}

Heizer \& Render (2016) state that manufacturing comes from the word "manufacture" namely a process done through machines to produce an item. Manufacturing industry is the backbone of the national economy. Tarjo \& Hartono (2003) argue that manufacturing company is quite sensitive to any changes in conditions. Manufacturing company certainly needs more sources of funds that can be used in the long term to finance the company's operations. One of the ways that can be used to protect this industry is through stock investment which will be related to the distribution of dividends. The growth of manufacturing organizations in this sector controls a strong position on economic growth in Indonesia because it is directly correlated with purchasing power and the needs of daily life. Therefore, the company

Journal of Business and Management Review Vol. 2 No. 82021 Page 517-530

DOI: $10.47153 /$ jbmr28.1892021

*Corresponding Author

Email address: muhammad.17080574083@mhs.unesa.ac.id 
profit receipts are closely related to the dividend policy, because the distribution of profits through dividends comes from the profits gained.

Sartono (2010) states that dividend policy is the decision becoming profit obtained by the company can be given to shareholders as dividends or can be held in the form of retained profits as investment funding in the future. The dividend policy will affect the total budgeted profit that can be distributed to the company's investors as well as the budgeting of the retained profit of the organization. According to Azhagaiah \& Priya (2008) distributed dividend is an important factor that determines shareholder wealth. The allocation of profit raises various conflicts that are experienced by the company.

The study results of Aharony \& Swary (1980) stating that the information provided at the time of the dividend announcement is more valuable than the earnings announcement. In line with Aharony \& Swary (1980) claiming that stable dividend distribution policy is expected to provide information to increase investor trust in making investment decision. A company's dividend policy certainly needs to pay attention on several aspects, including: liquidity, leverage, profitability, firm size, growth, institutional ownership, and managerial ownership. In addition, the information contained can be used by investors to assist in making investment decisions.

The liquidity variable reflects the company's ability to meet short-term obligations that must be fulfilled immediately (Prasidina et al., 2016). A company with high liquidity level provides a signal to investors that the company will try to pay dividends to shareholders as a form of responsibility for some of the funds given to run the company. This situation makes investors interested in investing or adding their capital so that they can gain profit in the form of dividends. This positive relation is strengthened by the research conducted by Adnyana \& Badjra (2014), Novita Sari \& Sudjarni (2015), Diantini \& Badjra (2016), and Ratnasari \& Purnawati (2019). However, it is also found that the effect of liquidity is negative; this result was found by (Nurhayati, 2013). In other research, it is found that liquidity does not affect dividend policy; this result was found by Arilaha (2009), Ginting (2018), and Dewantara et al. (2019).

Leverage variable can show the relation between long-term loans provided by creditors and the amount of own capital provided by the owner of the company (Syamsudin, 2009). The use of excessive debt has an unfavorable impact on the company because the company creates conditions to pay its obligations which will reduce the profit earned by the company. The distribution of dividends in the 
company is also influenced by debt in which debt is used to finance the expansion of the company, then to anticipate excessive debt, the company must have planned several ways to repay the debt. The negative effect of leverage is supported by the research done by Novita Sari \& Sudjarni (2015), Natalia \& Santoso (2017), Madyoningrum (2019), and Moeljono \& Alfianto (2020) In other research, it is found that leverage does not affect dividend policy; this result was found by Arilaha (2009), Mangantar \& Sumanti (2015), Ginting (2018), Dewantara et al. (2019), Ratnasari \& Purnawati (2019), and Machfiro et al. (2017).

Profitability variable is the ability of a company to gain profit (profit) at a certain level of sales, assets, and share capital (Husnan, 2001). Profitability is the company's ability to earn a certain profit. It is used as one of the factors to consider when making an investment. The number of profitability level indicates that the greater the level of profit obtained by the company. The high level of profitability can be a signal for investors that the company is profitable in the future. Positive profitability is supported by Nurhayati (2013), Shevina \& Sulistyani (2015), Natalia \& Santoso (2017), Setiyowati \& Sari (2017), Ginting (2018), and Madyoningrum, (2019). According to other studies, the effect of profitability shows negative research results supported by Nuringsih (2005), and Dewi (2008). At high levels of profitability, firms allocate low dividends. Jensen, Solberg and Zom (1992) cited in Nuringsih (2005). This is because the company allocates most of its profits as an internal source of funds. While, in other researches, it is found that profitability does not affect dividend policy; this result was found by Fimanda et al. (2015), Mangantar \& Sumanti (2015), Novita Sari \& Sudjarni (2015), Dewantara et al. (2019), and Moeljono \& Alfianto (2020).

Firm size variable is a tool that can be used to reflect the size of the company based on the company's total assets. Company size is one of the factors that influences dividend policy. According to Lopolusi, (2013) firm size also determines the amount of dividends to be paid because the larger the size of the company, the higher the turnover and profit generated; if the profit is high, the dividends distributed are also higher. The positive effect of firm size is supported by Dewi (2008), Fimanda et al. (2015), Rais \& Santoso (2017), and Madyoningrum (2019). According to other studies, the effect of firm size is contrary to dividend policy. The negative effect of firm size is supported by the research of Nurhayati (2013), and Adnyana \& Badjra (2014). While, the research conducted by Nuringsih (2005) stating that firm size does not have effect on the Dividend Payout Ratio (DPR).

Growth variable is one of the factors that influences dividend policy. In one case, the faster the growth rate of a company, the greater the need for funds required to finance this growth. The greater the need for funds in the future makes the company 
to be more inclined to hold its profits rather than pay them as dividends to investors. Dividend policy with a good growth rate will definitely allocate funds owned by the company to invest so that it will reduce the distribution of dividends to shareholders (Brigham \& Houston, 2011). The negative growth effect is supported by research Novita Sari \& Sudjarni (2015), and Ratnasari \& Purnawati (2019) where the faster the growth rate of a company, the greater the need for funds needed to finance this growth. Different things are obtained from the research conducted by Natalia \& Santoso (2017), and Diantini \& Badjra (2016), stating that growth does not have effect on the Dividend Payout Ratio (DPR).

Institutional ownership variable is the ownership of company shares by financial institutions such as insurance companies, banks, pension funds, and investment banking (Veronica \& Utama, 2005). Through ownership by institutions such as insurance companies, banks, investment companies and ownership by other institutions, it will increase more optimal supervision. Monitoring that occurs due to institutional ownership will ensure an increase in shareholder wealth. If institutions are dissatisfied with managerial performance, they will sell their shares to the market. Therefore, dividend policy will be influenced by institutional ownership factors. Dewi (2008), and Mangasih \& Asandimitra (2017) states that institutional ownership has a negative effect on dividend policy. It is stated to have a negative effect because an increase in institutional ownership will reduce the potential for dividend distribution. While, Fimanda et al. (2015), and Kurniawati et al. (2015) state that institutional ownership has a positive effect on dividend policy because institutional ownership is more concerned with income stability (return) through dividend distribution. Other research done by Rais \& Santoso (2017), and Balagobei (2017) state that institutional ownership does not have effect on the Dividend Payout Ratio (DPR).

Managerial ownership variable is the level of share ownership of the management who actively participates in decision making, for example directors and commissioners (Wahidawati, 2002). According to Mahadwartha \& Hartono (2002) the greater the proportion of management ownership in the company makes the management try harder for the benefit of the shareholders who incidentally are themselves, meaning that managerial ownership is able to influence dividend policy. The negative effect of managerial ownership is supported by research of Dewi (2008), and Fimanda et al. (2015). Meanwhile, the positive effect of managerial ownership is supported by research conducted by Mangantar \& Sumanti (2015), In the study, it is explained that when the commissioners and directors play an active role in decision making, it will create a tendency to prosper the shareholders by paying dividends. In 
other research done by Rais \& Santoso (2017) it shows that managerial ownership does not have effect on the Dividend Payout Ratio (DPR).

This research aims to find out the impact of financial factors (current ratio, debt to equity ratio, return on assets ratio, firm size, growth) and corporate governance (institutional ownership, managerial ownership) on dividend decisions of manufacturing companies in the consumer goods sector for the period 2016-2019.

\section{Literature Review}

\section{Dividend Policy}

Tandelilin (2010) argues that signalling theory states the assumption that news asymmetry in the market makes managers carry out news evaluations by providing real and clear answers that can be used as signals that distinguish them from other companies. According to dividend signaling theory, an increase in dividends will make the market react positively if the market tends to interpret that an increase in dividends is considered a good signal about the company's bright prospects in the future, otherwise the market will react negatively if there is a decrease in dividends, which is considered a bad signal about the company's prospects in the future (Bhattacharya, 1979).

Agency theory is a concept that describes the contractual correlation between principals and agents (Jensen \& Meckling, 1976). The interest differences lead to a conflict, which is commonly referred to as an agency conflict. In order to reduce agency problems, a company must incur costs known as agency costs. Agency costs have an effect with a company's dividend policy. The increase in the level of agency costs is a bad sign for shareholders because shareholders will receive a low level of dividends due to the use of excess funds by the management.

According to Sartono (2010), dividend policy is a decision that the profits obtained by the company can be given to shareholders as dividends or can be held in the form of retained profits as investment funding in the future.

\section{Liquidity}

Sartono (2010) states that liquidity is the ability of an organization to carry out shortterm financial obligations on time. Liquidity has a direct relation with dividend policy, where the greater the level of liquidity of a company, the greater the company ability to pay dividends (Sartono, 2010). This statement is strengthened by the research conducted by Adnyana \& Badjra (2014), Novita Sari \& Sudjarni (2015), Diantini \& Badjra (2016), and Ratnasari \& Purnawati (2019). 
H1: Liquidity has a positive effect on dividend policy in manufacturing companies in the consumer goods sector for the period 2016-2019

\section{Leverage}

Debt to equity ratio is one of the ratios used to calculate debt to equity (Kasmir, 2008). The greater the debt to equity ratio (DER) indicates the greater the level of the company dependence on external parties (creditors) and the greater the burden of debt costs that must be paid by the company, then the increase in debt will reduce net income. The reduction in net income will result in a reduction in dividends that will be received by shareholders. This statement is strengthened by the research conducted by Novita Sari \& Sudjarni (2015), Natalia \& Santoso (2017), Madyoningrum (2019), and Moeljono \& Alfianto (2020)

H2: The company leverage has a negative effect on dividend policy in manufacturing companies in the consumer goods sector for the period 2016-2019

\section{Profitability}

Kasmir (2008) argues that the profitability ratio is a ratio to assess the company ability to calculate profit. The increase in the company net profit increases the rate of return on investment in the form of dividend income for investors. This statement is strengthened by the research conducted by Dewi (2008), Fimanda et al. (2015), Rais \& Santoso (2017), and Madyoningrum (2019).

H3: Profitability has a positive effect on dividend policy in manufacturing companies in the consumer goods sector for the period 2016-2019

\section{Firm Size}

Companies that have a large size will more easily enter the capital market so that with this opportunity, the company pays large dividends to shareholders (Weston \& Copeland, 1996). This statement is strengthened by the research conducted by Dewi (2008), Fimanda et al. (2015), Rais \& Santoso (2017), and Madyoningrum (2019)

H4: Firm size has a positive effect on dividend policy in manufacturing companies in the consumer goods sector for the period 2016-2019

\section{Growth}

Tampubolon (2005) states that the company's growth rate is one of the factors that affect the dividend payout ratio. The faster the growth rate of a company, the greater the need for funds needed by the company. This statement is strengthened by the 
research conducted by Novita Sari \& Sudjarni (2015), and Ratnasari \& Purnawati (2019).

H5: Growth has a negative effect on dividend policy in manufacturing companies in the consumer goods sector for the period 2016-2019

\section{Institutional Ownership}

Scott (2000) claims that a high level of institutional ownership will result in more intensive monitoring efforts so that it can limit the manager opportunistic behavior, namely managers report earnings opportunistically to maximize their personal interests. Referring to agency theory, supervision agency costs result in a decrease in the amount of dividend distribution to investors. This statement is strengthened by the research conducted by Dewi (2008), and Mangasih \& Asandimitra (2017).

H6: Institutional ownership has a negative effect on dividend policy in manufacturing companies in the consumer goods sector for the period 2016-2019

\section{Managerial Ownership}

Mangantar \& Sumanti (2015) explain that when the commissioners and directors play an active role in decision making, there will be a tendency to prosper the shareholders by paying dividends. On the other hand, supervision creates agency costs which have an impact on decreasing the amount of dividends distributed to investors. This statement is strengthened by the research conducted by Dewi (2008), and Fimanda et al. (2015).

H7: Managerial ownership has a negative effect on dividend policy in manufacturing companies in the consumer goods sector for the period 2016-2019

\section{Method}

This research used quantitative data types by using secondary data sources that appear through financial reports and websites such as www.idx.co.id, www.sahamok.com, and the websites of each company. The population used in this research were manufacturing companies in the consumer goods sector listed on the Indonesia Stock Exchange for the period 2016-2019. The sampling technique in this research used purposive sampling, namely the sampling method using specified requirements. The requirements for selecting the sample are: manufacturing companies in the consumer goods sector on the Indonesian stock exchange with an observation period (2016-2019), manufacturing companies in the consumer goods sector that actively submit their financial reports during the observation period (2016- 
2019), and manufacturing companies the consumer goods sector did not experience delisting and relisting in the period (2016-2019). According to the category, a research sample of 34 manufacturing companies in the consumer goods sector was obtained. Next, it is multiplied by 4 observation periods (2016-2019) to obtain 136 observations. Classical assumption testing aimed to test the validity of the data from the secondary data obtained. The dependent variable used is dividend policy proxied by dividend payout ratio and the independent variables used are liquidity, leverage, profitability, firm size, growth, institutional ownership, and managerial ownership. The objective of this research is to determine the correlation between the independent variable and the dependent variable during certain events.

\section{Result and Discussion}

Table 1. Descriptive Statistic Table

\begin{tabular}{cccccc}
\hline & $\mathrm{N}$ & Min & Max & Mean & Std. Deviation \\
\hline Dividen Payout Ratio & 82 & $-0,372$ & 1,004 & 0,282 & 0,308 \\
\hline Likuidity & 82 & 0,754 & 6,110 & 2,739 & 1,347 \\
\hline Leverage & 82 & 0,087 & 2,238 & 0,646 & 0,441 \\
\hline Profitability & 82 & $-0,155$ & 0,295 & 0,072 & 0,086 \\
\hline Firm Size & 82 & 25,664 & 32,201 & 28,840 & 1,861 \\
\hline Growth & 82 & $-0,105$ & 0,218 & 0,064 & 0,064 \\
\hline $\begin{array}{c}\text { Institutional } \\
\text { Ownership }\end{array}$ & 82 & 0,195 & 0,998 & 0,735 & 0,166 \\
\hline $\begin{array}{c}\text { Managerial } \\
\text { Ownership }\end{array}$ & 82 & 0,000 & 0,252 & 0,013 & 0,037 \\
\hline
\end{tabular}

Source: SPSS 26 Output (data were processed)

\section{Outlier Data}

In this study, some of the data were detected as outliers which caused bias in the research results, resulting in a reduction in observational data, from a total of 136 observational data to 82 observational data. Factors for the emergence of data outliers, including: (1) errors when inputting data, (2) errors in dividing when missing values in computer applications, (3) outliers not being part of the population that we use as samples, and (4) outliers arising from populations used as a sample, but the distribution included variables in the population that have extreme results and were not normally distributed (Ghozali, 2016).

\section{Goodness of Fit}


Table 2. Regression Coefficient

\begin{tabular}{cccccc}
\hline & $\begin{array}{c}\text { Unstandar } \\
\text { dized B }\end{array}$ & $\begin{array}{c}\text { Coefficients } \\
\text { Std. Error }\end{array}$ & $\begin{array}{c}\text { Standardized } \\
\text { Coefficients } \\
\text { Beta }\end{array}$ & $\mathrm{T}$ & Sig. \\
\hline (Constant) & $-1,222$ & 0,443 & & $-2,756$ & 0,007 \\
\hline Liquidity & 0,017 & 0,023 & 0,076 & 0,762 & 0,448 \\
\hline Leverage & $-0,100$ & 0,069 & $-0,143$ & $-1,446$ & 0,152 \\
\hline Profitability & 1,872 & 0,361 & 0,525 & 5,180 & 0,000 \\
\hline Firm Size & 0,045 & 0,014 & 0,274 & 3,231 & 0,002 \\
\hline Growth & $-0,797$ & 0,380 & $-0,166$ & $-2,096$ & 0,039 \\
\hline $\begin{array}{c}\text { Institutional } \\
\text { Ownership }\end{array}$ & 0,186 & 0,147 & 0,100 & 1,270 & 0,208 \\
\hline $\begin{array}{c}\text { Managerial } \\
\text { Ownership }\end{array}$ & $-0,682$ & 0,664 & $-0,083$ & $-1,028$ & 0,307 \\
\hline Adj R Square & 0,594 & & & & \\
\hline F & 17,913 & & & & 0,000
\end{tabular}

Source: SPSS 26 Output (data were processed)

Hypothesis testing in this research implements multiple linear regression equations. According to table 2, the following multiple linear regression equation can be found:

$Y=-1,222+1,872 R O A+0,045 F S-0,797 G R T H+\varepsilon$

\section{Effect of Liquidity on Dividend Payout Ratio}

The analysis output obtained proved that there was no significant effect between the liquidity proxied by the current ratio and the dividend payout ratio. The results of this research are not in accordance with signaling theory, the increase in company liquidity is expected to be a signal or sign that the company will improve the company ability to pay dividends. One of the causes of this is the interest of the company which focuses more on liquidity to finance its short-term obligations when compared to focusing on distributing dividends. In addition, the company avoids increasing the amount of debt that will burden the company. Therefore, changes in the level of liquidity owned by the company do not guarantee the company will change the level of dividend payments to investors. The results obtained in this research are in line with previous research conducted by Arilaha (2009) and Ginting (2018) where the dividend payout ratio does not consider liquidity (current ratio) in dividend policy.

Effect of Leverage on Dividend Payout Ratio 
The output of this research is not in accordance with signaling theory and is in line with research by Arilaha (2009), Mangantar \& Sumanti (2015), Ginting (2018), Dewantara et al. (2019), Ratnasari \& Purnawati (2019), and Machfiro et al. (2017) proving that there is no significant effect between leverage proxied by the debt to equity ratio and the dividend payout ratio. One of the reasons is that companies still pay attention on the interests of the owners of capital even though the company debt has increased. This treatment is one of the ways to maintain the trust of investors who have invested their capital. In addition, the increase in debt becomes meaningless if it is followed by an increase in company profits, because the company is able to cover debt through increased profits generated. Therefore, as long as the company is committed to paying dividends and the manager is able to manage loan capital well, the increase in debt will not have an effect on the dividend payout ratio.

\section{Effect of Profitability on Dividend Payout Ratio}

The output of the analysis that has been carried out proves that there is a relation between the level of profit proxied from the return on assets to the dividend payout ratio with the direction of a positive relation. This means that these results are in accordance with signaling theory and research conducted by Nurhayati (2013), Shevina \& Sulistyani (2015), Natalia \& Santoso (2017), Setiyowati \& Sari (2017), Ginting (2018), and Madyoningrum, (2019) stating that companies with high profitability have the ability to generate greater profits, increased profits increase the company ability to meet its short-term obligations, as well as the ability to pay a number of benefits to investors through dividend distribution. Therefore, when the company profitability decreases, it will be followed by a decrease in the company's dividend payout ratio and vice versa. Therefore, companies with high profitability can signal higher dividend decisions to investorsi.

\section{Effect of Firm Size on Dividend Payout Ratio}

The output of the analysis proves that there is a relation between firm size and dividend payout ratio using a positive correlation direction. This means that the firm size results are in line with the research by Dewi (2008), Fimanda et al. (2015), Rais \& Santoso (2017), dan Madyoningrum (2019) and signaling theory, namely the larger the size of the company, the higher the dividends given by the company. Companies with large sizes have the ability to pay large dividends in order to control the trust and image of the investor group of companies. In addition, the size of the company will make it easier for the company to gain profits, but in contrast to the small firm size, it can only budget profits to retained profits in order to increase company assets so that companies tend to provide small dividends. 


\section{Effect of Growth on Dividend Payout Ratio}

The output of the analysis proves that there is a correlation between company growth and the dividend payout ratio with the aim of a negative correlation. This means that growth is in line with research conducted by Novita Sari \& Sudjarni (2015), and Ratnasari \& Purnawati (2019) and signaling theory, namely the greater the company growth rate, the lower the total dividends given to each shareholder. The condition that can cause this is due to the increasing level of company cost requirements. Asset growth is often budgeted during operational activities until some of the company assets are held. The greater the level of increase in the company, the greater the level of need for funds to fund the number of companies. An increase in retained profits indicates that there is an increase in the company own capital obtained with low-cost funds. Therefore, managers prefer funding the expansion of the company to being distributed to investors in the form of dividends.

\section{Effect of Institutional Ownership on Dividend Payout Ratio}

The output of this research is not in line with agency theory and shows that there is no effect between institutional ownership on the dividend payout ratio. Institutional ownership of the company is essentially adding control to the company management to assess the institution's work professionally and review the company. One of the reasons for the insignificant impact of institutional ownership on dividend decisions in this research is that the management of the company has succeeded in minimizing the friction between the interests of institutional investors and general investors which will cause agency costs. Basically, institutional investors have different goals from general investors. The point of view of institutional investors is to invest some of their funds for a long time, they prioritize companies to reinvest their profits compared to companies that allocate a large part of their profits to dividends, while general investors tend to want to immediately enjoy a number of funds invested in the short term. Therefore, the number of shares owned by the institution does not have effect on the level of dividend payments made by the company. These results are in line with research conducted by Rais \& Santoso (2017), dan Balagobei (2017).

\section{Effect of Managerial Ownership on Dividend Payout Ratio}

The output of this research is not in line with agency theory and is in line with research by Rais \& Santoso (2017) proving that there is no significant impact between managerial ownership on the dividend payout ratio. The size of the dividend payment does not depend on how high or low the level of managerial ownership is. Because managerial ownership does not affect the company ability to pay off its obligations, it 
is through share ownership that a manager will get the opportunity to be directly involved in balancing the interests of the company with shareholders. The involvement of share ownership can be interpreted that managers will act carefully because they share the consequences for the decisions taken. On the other hand, managers will be motivated to improve their performance in managing the company.

In this research, not many manufacturing companies implement managerial ownership policies, so that most of the companies sampled in this research do not have managerial ownership in their capital structure.

\section{Conclusion}

The conclusion that can be drawn is that profitability, firm size, and growth affect the dividen policy based on the analytical and previous discussions. On the other hand, liquidity in this study does not have effect on dividend policy. One of the causes of this is that liquidity is used to finance short-term obligations compared to focusing on distributing dividends. Leverage in this study does not have effect on dividend policy. The reasons is that companies still pay attention on the interests of the owners of capital even though the company debt has increased. Institutional ownership and Managerial ownership, in this study, does not have effect on dividend policy. The reasons is the success of the company management in minimizing the friction between the interests of institutional investors and general investors which will cause agency costs and ownership of shares by a manager will condition the equalization of the company interests with shareholders. Share ownership can mean that managers will act carefully because they share the consequences for the decisions they make.

The implications of this research are expected to be used by related parties including investors, manufacturing companies, and further researchers with similar topic. This research is also expected to be used as material for decision-making and policies for the parties concerned. Companies that consider profitability, firm size, and growth are expected to use this research as consideration for improving company performance and determining company policies. Investors who consider profitability, firm size, and growth are expected to use research to assist decision making in investing their capital. This study has several limitations, namely there is another dependent variable that can be used as a determinant of dividend policy, namely dividend yield. Dividend yield is the level of profit that is distributed from the company to investors. Therefore, further similar research can be carried out by using dividend yield as a determinant variable for dividend policy.

\section{References}


Adnyana, I., \& Badjra, I. (2014). Pengaruh Likuiditas, Manajemen Aktiva, EPS, dan Ukuran Perusahaan terhadap Kebijakan Dividen dan Nilai Perusahaan. E-Jurnal Manajemen Universitas Udayana, 3(12), 3707-3724.

Aharony, J., \& Swary, I. (1980). Quarterly Dividend and Earnings Announcements and Stockholders Returns: An Empirical Analysis. The Journal of Finance, 35(1), 1-12.

Arilaha, M. A. (2009). Pengaruh Free Cash Flow, Profitabilitas, Likuiditas, dan Leverage terhadap Kebijakan Dividen. Jurnal Keuangan Dan Perbankan, 13(1), 7887.

Azhagaiah, R., \& Priya, S. (2008). The Impact of Dividend Policy on Shareholders' Wealth. International Research Journal of Finance and Economics, 181-187.

Balagobei, S. (2017). Impact of Institutional Ownership and Individual Ownership on Dividend Policy of Listed Plantation Companies in Sri Lanka. Asia Pacific Journal of Advanced Business and Social Studies (APJABSS), 3(1), 329-335.

Bhattacharya, S. (1979). Imperfect Information, Dividend Policy, and the Bird in the Hand Fallacy Bell. Journal of Economics, 10(1), 259-270.

Brigham, E. F., \& Houston, J. F. (2011). Dasar-Dasar Manajemen Keuangan (10th ed.). Jakarta: Salemba Empat.

Dewantara, A. B., Siswanto, \& Rizqi, A. M. (2019). Profitability and Leverage, and The Implication on the Dividend Policy of Jakarta Islamic Index. EL DINAR: Jurnal Keuangan Dan Perbankan Syariah, 7(1), 1-15.

Dewi, S. C. (2008). Pengaruh Kepemilikan Managerial, Kepemilikan Institusional, Kebijakan Hutang, Profitabilitas dan Ukuran Perusahaan terhadap Kebijakan Dividen. JURNAL BISNIS DAN AKUNTANSI, 10(1), 47-58.

Diantini, O., \& Badjra, I. (2016). Pengaruh Earning Per Share, Tingkat Pertumbuhan Perusahaan dan Current Ratio terhadap Kebijakan Dividen. E-Jurnal Manajemen Universitas Udayana, 5(11), 6795-6824.

Fimanda, R., Raharjo, K., \& Oemar, A. (2015). Pengaruh Kepemilikan Manajerial, Kepemilikan Institusional. Kebijakan Hutang, Profitabilitas, Ukuran Perusahaan, dan Cash Position terhadap Kebijakan Dividen. Jurnal Universitas Pandanaran Semarang, 2(4), 1-20.

Ghozali, I. (2016). Aplikasi Analisis Multivariate dengan Program IBM SPSS 23 (Edisi 8). Semarang: Badan Penerbit Universitas Diponegoro.

Ginting, S. (2018). Pengaruh Likuiditas, Profitabilitas, dan Leverage terhadap Kebijakan Deviden pada Perusahaan LQ46 yang Terdaftar di Bursa Efek Indonesia Periode 2012-2016. Jwem Stie Mikroskil, 8(2), 195-204.

Heizer, J., \& Render, B. (2016). Manajemen Operasi: Manajemen Keberlangsungan dan Rantai Pasokan (Edisi 11) (11th ed.). Jakarta: Salemba Empat.

Husnan, S. (2001). Dasar-Dasar Teori Portofolio dan Analisis Sekuritas. AMP YPKN.

Jensen, M. C., \& Meckling, W. H. (1976). Theory of the firm: Managerial behavior, agency cost and ownership structure. Journal of Finance Economic, 3(4), 305-360.

Kasmir. (2008). Analisis Laporan Keuangan (1st ed.). Jakarta: Rajawali Press.

Kurniawati, L., Manalu, S., \& Ovtavianus, R. J. N. (2015). Pengaruh Kepemilikan Institusional terhadap Kebijakan Dividen, dan Harga Saham. Jurnal Manajemen, 15(1), 59-74. https://journal.maranatha.edu/index.php/jmm/article/view/26 
Lopolusi, I. (2013). Analisis Faktor-Faktor yang Mempengaruhi Kebijakan Dividen Sektor Manufaktur yang Terdaftar di Bursa Efek Indonesia Periode 2007-2011. Jurnal Ilmiah Mahasiswa Universitas Surabaya, 2(1), 1-18.

Machfiro, S., Sukoharsono, E. G., \& Nuzula, N. F. (2017). The Reciprocal Effect of Leverage, Dividend Policy, and Financial Performance: Study on Comparison Between Mining and Trade, Services, Investment Companies Listed on Indonesia Stock Exchange Period of 2010-2014. Russian Journal of Agricultural and SocioEconomic Sciences, 63(3), 122-136. https://doi.org/10.18551/rjoas.2017-03.15

Madyoningrum, A. W. (2019). Pengaruh Firm Size, Leverage dan Profitabilitas terhadap Kebijakan Deviden. Jurnal Bisnis Dan Manajemen, 6(1), 45-55. https:/ / doi.org/10.26905/jbm.v6i1.3034

Mahadwartha, P. A., \& Hartono, J. (2002). Uji Teori Keagenan dalam Hubungan Interpendensi antara Kebijakan Hutang dengan Kebijakan Dividen. Simposium Nasional Akuntansi $V$.

Mangantar, M., \& Sumanti, J. C. (2015). Analisis Kepemilikan Manajerial, Kebijakan Hutang dan Profitabilitas terhadap Kebijakan Dividen dan Nilai Perusahaan pada Perusahaan Manufaktur yang Terdaftar di BEI. Jurnal Riset Ekonomi, Manajemen, Bisnis Dan Akuntansi, 3(1), 1141-1151. https:/ / doi.org/10.35794/emba.v3i1.7928

Mangasih, G. V., \& Asandimitra, N. (2017). Pengaruh Insider Ownership, Institutional Ownership, Dispersion of Ownership, Collateralizable Assets, dan Board Independence terhadap Kebijakan Dividen pada Sektor Finance Periode 20112015. Jurnal Ilmu Manajemen (JIM), 5(3), 1-8.

Moeljono, \& Alfianto, N. (2020). Peran Size dalam Memoderasi Pengaruh Profitabilitas, Invesment Oppourtunity Set dan Leverage terhadap Kebijakan Dividend. Jurnal Ekonomi Dan Bisnis (EKOBIS), 21(1), 26-50.

Natalia, E., \& Santoso, H. F. (2017). Pengaruh Arus Kas Bebas, Pertumbuhan Perusahaan, Rasio Total Utang dan Modal Sendiri, Rasio Laba Bersih dan Total Aset terhadap Kebijakan Deviden. Jurnal Akuntansi, 17(1), 33-46.

Novita Sari, K., \& Sudjarni, L. (2015). Pengaruh Likuiditas, Leverage, Pertumbuhan Perusahaan, dan Profitabilitas terhadap Kebijakan Dividen pada Perusahaan Manufaktur di BEI. E-Jurnal Manajemen Universitas Udayana, 4(10), 3346-3374.

Nurhayati, M. (2013). Profitabilitas, Likuiditas, dan Ukuran Perusahaan Pengaruhnya terhadap Kebijakan Dividen dan Nilai Perusahaan Sektor Non Jasa. Jurnal Keuangan Dan Bisnis, 5(2), 144-153.

Nuringsih, K. (2005). Analisis Pengaruh Kepemilikan Manajerial, Kebijakan Utang, Roa dan Ukuran Perusahaan Terhadap Kebijakan Dividen: Studi 1995-1996. Jurnal Akuntansi Dan Keuangan Indonesia, 2(2), 103-123. https://doi.org/10.21002/jaki.2005.12

Prasidina, D. G., Ekonomi, F., Islam, U., \& Catur, C. (2016). Analisis Pengaruh Profitabilitas, Likuiditas, dan Kesempatan Investasi terhadap Kebijakan Deviden pada Perusahaan Manufaktur yang Terdaftar di BEI Periode 2013-2016.

Rais, B. N., \& Santoso, H. F. (2017). Pengaruh Kepemilikan Manajerial, Kepemilikan Institusional, Profitabilitas dan Ukuran Perusahaan terhadap Kebijakan Deviden. Jurnal Ilmiah Manajemen Bisnis, 17(2), 111-124. 
Ratnasari, P. S. P., \& Purnawati, N. K. (2019). Pengaruh Profitabilitas, Likuiditas, Tingkat Pertumbuhan Perusahaan dan Leverage terhadap Kebijakan Dividen. EJurnal Manajemen Universitas Udayana, 8(10), 6179. https:// doi.org/10.24843/ejmunud.2019.v08.i10.p16

Sartono, A. (2010). Manajemen Keuangan: Teori dan Aplikasi Edisi 4 (4th ed.). Yogyakarta: BPFE.

Scott, W. R. (2000). Financial Acounting Theory. Ontario: Prentice Hall Canada Inc.

Setiyowati, S. W., \& Sari, A. R. (2017). Pengaruh Corporate Governance dan Kinerja Keuangan terhadap Kebijakan Deviden pada Perusahaan Manufaktur Yang Listing di Bursa Efek Indonesia Tahun 2014-2015. Jurnal AKSI (Akuntansi Dan Sistem Informasi), 1(1), 45-57. https:/ / doi.org/10.32486/aksi.v1i1.95

Shevina, A. D., \& Sulistyani, T. (2015). Pengaruh Tingkat Pertumbuhan Perusahaan, Return on Assets (ROA) dan Shareholder Dispersion terhadap Kebijakan Deviden pada Industri Manufaktur di Bursa Efek Indonesia Periode 2011-2013. Jurnal Fokus, 5(2), 145-157.

Syamsudin, L. (2009). Manajemen Keuangan Perusahaan: Konsep Aplikasi dalam: Perencanaan, Pengawasan, dan Pengambilan Keputusan. Jakarta: Rajawali Pers.

Tampubolon, M. P. (2005). Manajemen Keuangan (Finance Management). Bogor: Ghalia Indonesia.

Tandelilin, E. (2010). Portofolio dan Investasi. Yogyakarta: Kanisius.

Tarjo, \& Hartono, J. (2003). Analisa Free Cash Flow dan Kepemilikan Manajerial terhadap Kebijakan Utang pada Perusahaan Publik di Indonesia. Prosiding Simposium Nasional Akuntansi VI, Surabaya, 16-17 Oktober, 278-295.

Veronica, S., \& Utama, S. (2005). Pengaruh Struktur Kepemilikan, Ukuran Perusahaan, dan Praktek Corporate Governance Terhadap Pengelolaan Laba (Earnings Management). Simposium Nasional Akuntansi (SNA).

Wahidawati. (2002). Kepemilikan Manajerial dan Agency Conflicts: Analisis Persamaan Simultan Non Liner dari Kepemilikan Manajerial, Penerimaaan Risiko, Kebijakan Utang dan Kebijakan Dividen. Prosiding Simposium Nasional Akuntans V, 601-623.

Weston, J. F., \& Copeland, T. E. (1996). Manajemen Keuangan Edisi Kedelapan Jilid 2. Jakarta: Erlangga. 